\title{
Storey Response of G+40 Horizontally Connected Buildings with Dampers
}

\author{
Mayuri M. Baviskar \\ Department of Civil Engineering \\ MGM's Jawaharlal Nehru Engineering College \\ Aurangabad, Maharashtra, India
}

\author{
Prof. L. G. Kalurkar \\ Department of Civil Engineering \\ MGM's Jawaharlal Nehru Engineering College \\ Aurangabad, Maharashtra, India
}

\begin{abstract}
Analyzing the response of structure to ground shaking caused by an earthquake is one the most important application of structural dynamics. Tall structures are more exposed to dynamic loads, earthquake and wind effects. Tall buildings are characterized by low natural frequency. Hence, they can vibrate significantly under lateral dynamic earthquake loads. This paper deals with the analysis of $\mathrm{G}+40$ storey buildings connected horizontally with the truss bridge at $21^{\text {st }}$ and $31^{\text {st }}$ storey having fixed base and shows the storey response curves of buildings connected with dampers and without dampers. The building frame type used is ordinary moment resisting frame (OMRF). The dampers used are fluid viscous dampers (FVD) having force capacity of $500 \mathrm{KN}$. The analysis is done using ETABS V16 software.
\end{abstract}

Keywords- Dampers, fluid viscous damper, storey response curve, fixed base, seismic response, ordinary moment resisting frame, ETABS V16.

\section{I.INTRODUCTION}

As the business activities demands to be on the point of one another and at the town centre, tall buildings get a lot of attention in today's life. Also, because they form distinctive landmark, tall buildings are oftentimes developed in town centers as status image for company organization. Due to the speedy increase in population and reduction in accessibility of land, vertical accommodation is obtaining a lot of preference which is resulting in vertical town development. The higher land costs, reduction in urban sprawl and for agricultural production, residential buildings are growing upward. Buildings are designed primarily to serve the needs of occupancy whether residential or commercial. At the same time, clients requirement regarding aesthetic qualities plays important role.

The modeling of high rise structure for analysis is depends on the approach of research. The bottom shaking that occurs in an earthquake are often represented as a series of multidirectional random acceleration pulses. The seismal response of tall building will depend on the dynamic properties of the structure, ground motion at the foundation and mode of soil structure interaction. Response spectrometry shows that how the structure will respond if damping is elicited. Various curves are developed with different levels of damping. As damping increases, response spectra shift downward. As per typical earthquake resistant design, structure is designed for forces which are much less than the actual design earthquake forces. Therefore, throughout earthquake event, structure undergoes severe non resilient deformation with non repairable damages. RCC structure can be made ductile with the help of reinforcing steel. Thus, to grasp whether or not the structure can all collapse or part collapse or wont collapse throughout or after earthquake, time history analysis is required to perform. The results obtained from analysis are studied to know the actual behavior of structure.
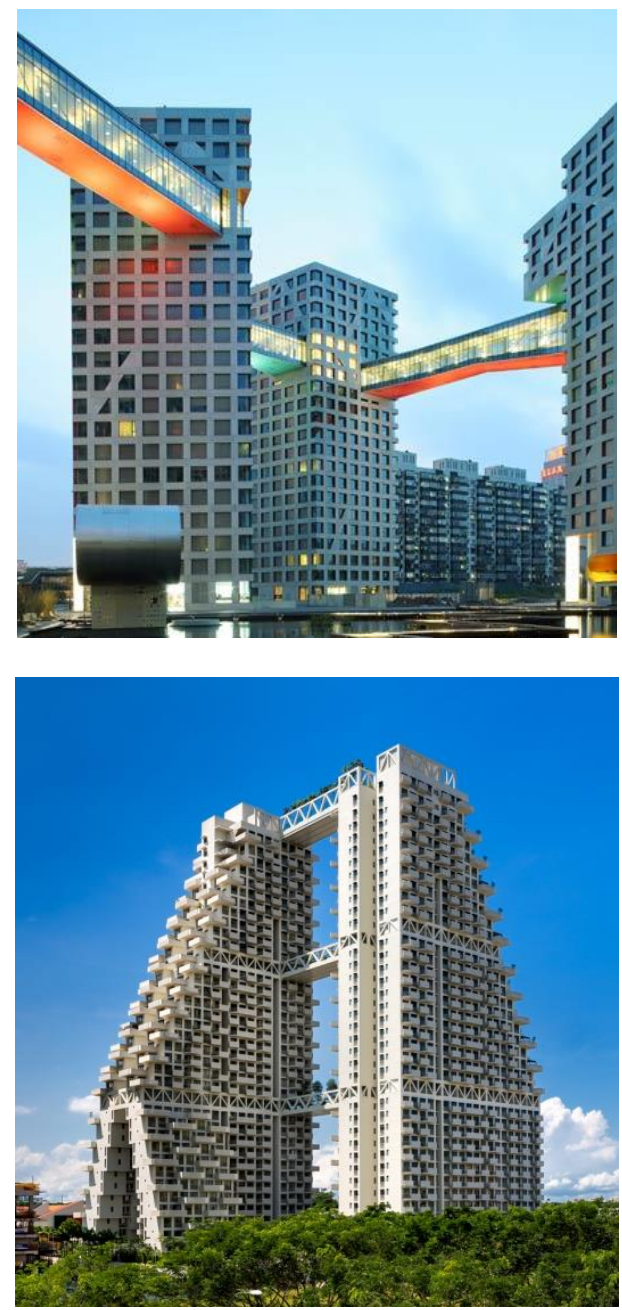

Fig 1: Real horizontally connected structures.

II.EXAMPLE BUILDING

Building set up chosen for this project is as shown in figure below. Two buildings are connected by a truss bridge of $50 \mathrm{~m}$ length at twenty first floor and thirty first floor. The structure is built with ordinary moment resisting frame (OMRF). Both buildings are symmetric to each other and considered to be served as residential building. Building is having forty storeys for accommodation purpose and top story as terrace. The columns are fixed at base. Two column sizes are utilized in 
structure. Column of size $0.85 \mathrm{~m} \times 0.65 \mathrm{~m}$ are used up to $10^{\text {th }}$ storey and $0.75 \mathrm{~m} \times 0.55 \mathrm{~m}$ are used for rest of the storey. Beams having cross sectional size $0.3 \mathrm{~m} \times 0.6 \mathrm{~m}$. The floor to floor height is kept constant as $3 \mathrm{~m}$ and slab thickness as $0.18 \mathrm{~m}$ throughout the structure. 4 lifts are provided at each floor per building. Shear wall of $0.3 \mathrm{~m}$ thick are used for the lift sections. Concrete grades used are M35 and M40 while steel used is of grade HYSD500. Instead of traditional brick wall Autoclave Aerated Concrete (AAC) Blocks are used as wall having unit weight ranging from $4.6 \mathrm{kN} / \mathrm{m}^{3}$ to $7.5 \mathrm{kN} / \mathrm{m}^{3}$ which is almost $1 / 3^{\text {rd }}$ of normal concrete. Building is analyzed for all zones for earthquake. Load combinations are taken as per IS 456:2000 and earthquake loading is taken as per IS 1893:2002. Load combinations used are listed below:

$1.5(\mathrm{DL}+\mathrm{LL})$

$1.5(\mathrm{DL} \pm \mathrm{EQx})$

$1.5(\mathrm{DL} \pm \mathrm{EQy})$

1.5(DL $\pm \mathrm{WLx})$

$1.5(\mathrm{DL}+ \pm \mathrm{WLy})$

$1.2(\mathrm{DL}+\mathrm{LL} \pm \mathrm{EQx})$

1.2(DL+LL $\pm E Q y)$

1.2(DL+LL $\pm \mathrm{WLx})$

1.2(DL+LL $\pm W L y)$

$0.9 \mathrm{DL} \pm 1.5 \mathrm{EQx}$

$0.9 \mathrm{DL} \pm 1.5 \mathrm{EQy}$

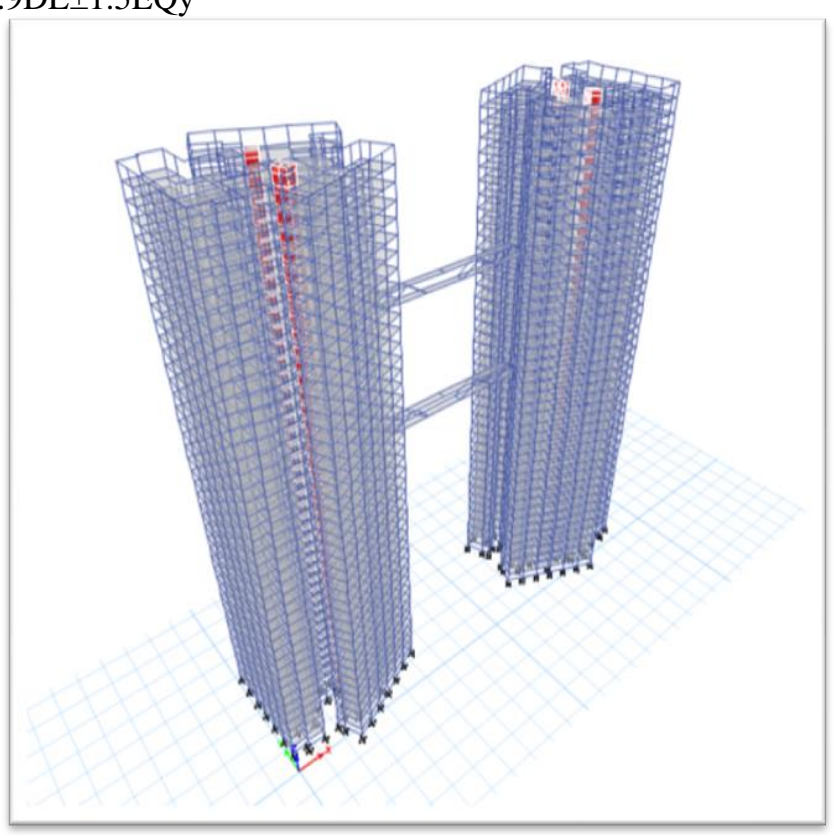

Fig 2: 3-D view of $\mathrm{G}+40$ building.

\section{A. Fluid Viscous Dampers:}

The fluid viscous dampers are hydraulic devices that dissipate the mechanical energy of seismal events and cushion the

impact between structures. They're versatile and might be designed to permit free movement in addition as controlled damping of a structure to safeguard from wind load, thermal motion or seismic events. The fluid viscous damper is consisting of oil cylinder, piston, piston rod, lining, medium, pin head and other main parts. The piston may create mutual motion within the oil cylinder. The piston is provided with damping structure and therefore the oil cylinder is jam-packed with fluid damping medium. Once the external stimulation (such as earthquake, wind vibration) reaches to the engineering structure, it'll be deformed and drive the damper to move, which will occur the pressure difference on the different side of the piston. Then the medium can undergo the damping structure and make damping power, which will occur the exchange of power (the mechanical power exchange to heat power). All which will reach the aim of reducing the engineering structure's vibration.

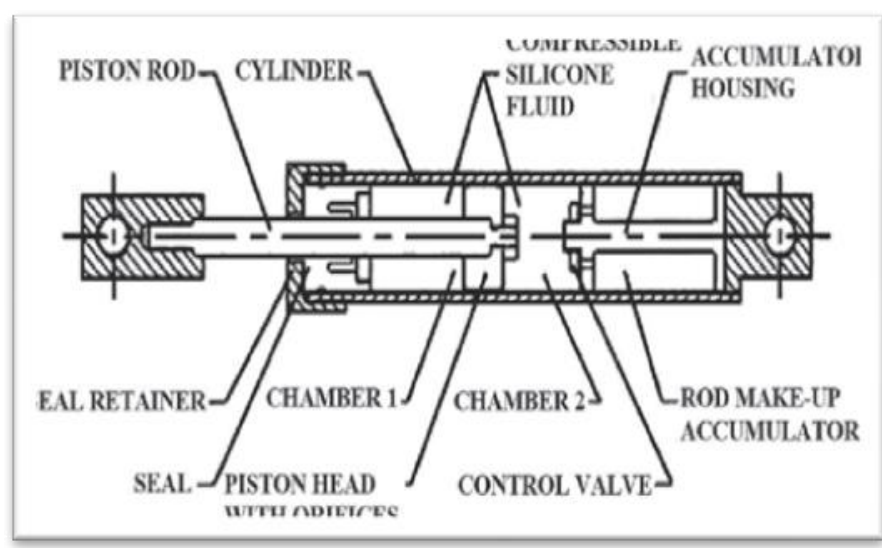

Fig 3: schematic diagram of Fluid Viscous Damper

Damper system are designed and made to safeguard structural integrities, management and stop structural damages by fascinating seismic energy and reduces deformations within the structure. Due to easy installation, adaptability, coordination with other members and variety in their sizes, viscous dampers have several applications in planning and retrofitting.

In this project, each building is connected with 6 fluid viscous dampers at alternate floors. Dampers having capacity of $500 \mathrm{kN}$ are used. Table showing damper capacity is shown below:

TABLE 1: FVD WITH DIFFERENT CAPACITIES FORCES (KN)

\begin{tabular}{|c|c|c|c|c|}
\hline $\begin{array}{c}\text { Force } \\
(\mathbf{k N})\end{array}$ & $\begin{array}{c}\text { Spherical } \\
\text { Bearing } \\
\text { Bore } \\
\text { Diameter } \\
(\mathbf{m m})\end{array}$ & $\begin{array}{c}\text { Stroke } \\
(\mathbf{m m})\end{array}$ & $\begin{array}{c}\text { Clevis } \\
\text { Thickness } \\
(\mathbf{m m})\end{array}$ & $\begin{array}{c}\text { Weight } \\
(\mathbf{k g})\end{array}$ \\
\hline 250 & 38.10 & \pm 75 & 43 & 44 \\
\hline 500 & 50.80 & \pm 100 & 55 & 98 \\
\hline 750 & 57.15 & \pm 100 & 59 & 168 \\
\hline 1000 & 69.85 & \pm 100 & 71 & 254 \\
\hline 1500 & 76.20 & \pm 100 & 77 & 306 \\
\hline 2000 & 88.90 & \pm 125 & 91 & 500 \\
\hline 3000 & 101.60 & \pm 125 & 117 & 800 \\
\hline 4000 & 127.00 & \pm 125 & 142 & 1088 \\
\hline 6500 & 152.40 & \pm 125 & 154 & 1930 \\
\hline
\end{tabular}

\section{B. Response Spectrum Analysis.}

Response spectra are curves plotted between maximum response of system subjected to specified earthquake ground motion and its time period (or frequency). Response spectrum can be interpreted as the locus of maximum response of a system for given damping ratio. Response spectra thus helps in obtaining the peak structural responses under linear range, which can be used for obtaining lateral forces developed in structure due to earthquake thus facilitates in earthquake- 
resistant design of structures. The three spectra i.e. displacement, pseudo velocity and pseudo acceleration provide the same information on the structural response. However, each one of them provides a physically meaningful quantity and therefore, all three spectra are useful in understanding the nature of an earthquake and its influence on the design. A combined plot showing all three of the spectral quantities is possible because of the relationship that exists between these three quantities.

\section{Time History Analysis:}

The actual method of mixing the various modal contributions is a probabilistic averaging technique and in some cases, results will not represent the actual behaviour of structure. Time history analysis overcomes this. However, it needs massive procedure efforts. The tactic consists of a step by step direct integration in which the time domain is discretized into a number of tiny increments and for every quantity the equation of motion is solved with the displacements and velocities of the previous step serving as initial functions. The tactic is applicable to both elastic and inelastic analyses. In elastic analysis, the stiffness characteristics of structure are assumed to be constant for whole duration of the earthquake. In inelastic analysis, the stiffness is assumed to be constant through the progressive time solely.

The proposed building in Zone $\mathrm{V}$ with site condition III is analysed for both response spectrum and time history analysis with time history data of El-Centro earthquake in 1940. The analysis is done for with damper condition and without damper condition also. 5\% damping is allowed in the structure. The graphs of Spectral Displacement Vs Period, Pseudo Spectral Velocity Vs Period and Pseudo Spectral Acceleration Vs Period are obtained which are shown in result section.

\section{III.RESULTS}

The proposed building in analyzed in different zones of earthquake and the displacement value of each storey are tabulated for with damper and without damper condition for each zone. Chart 1 shows the displacement values of building in Zone II with site type I. Chart 2 shows the displacement values of building in Zone III with site type III. Chart 3 shows the displacement values for Zone IV with site type II and chart 4 shows displacement values for Zone V with site type III.

TABLE 2: STOREY DISPLACEMENT IN ZONE II (X-DIRECTION)

\begin{tabular}{|c|c|c|}
\hline Storey & With Damper & Without Damper \\
\hline top & 66.266 & 79.234 \\
\hline $40^{\text {th }}$ floor & 65.392 & 77.96 \\
\hline $39^{\text {th }}$ floor & 64.115 & 76.563 \\
\hline $38^{\text {th }}$ floor & 62.787 & 75.087 \\
\hline $37^{\text {th }}$ floor & 61.397 & 73.549 \\
\hline $36^{\text {th }}$ floor & 59.954 & 71.944 \\
\hline $35^{\text {th }}$ floor & 58.478 & 70.269 \\
\hline $34^{\text {th }}$ floor & 56.919 & 68.524 \\
\hline $33^{\text {rd }}$ floor & 55.357 & 66.709 \\
\hline $32^{\text {nd }}$ floor & 53.686 & 64.828 \\
\hline $31^{\text {st }}$ floor & 52.042 & 62.884 \\
\hline $30^{\text {th }}$ floor & 50.269 & 60.88 \\
\hline $29^{\text {th }}$ floor & 48.551 & 58.82 \\
\hline $28^{\text {th }}$ floor & 46.69 & 56.707 \\
\hline $27^{\text {th }}$ floor & 44.907 & 54.548 \\
\hline $26^{\text {th }}$ floor & 42.974 & 52.346 \\
\hline
\end{tabular}

\begin{tabular}{|c|c|c|}
\hline $25^{\text {th }}$ floor & 41.141 & 50.107 \\
\hline $24^{\text {th }}$ floor & 39.152 & 47.836 \\
\hline $23^{\text {rd }}$ floor & 37.285 & 45.539 \\
\hline $22^{\text {nfloor }}$ & 35.258 & 43.221 \\
\hline $21^{\text {st }}$ floor & 33.373 & 40.888 \\
\hline $20^{\text {th }}$ floor & 31.328 & 38.545 \\
\hline $19^{\text {th }}$ floor & 29.446 & 36.199 \\
\hline $18^{\text {th }}$ floor & 27.405 & 33.859 \\
\hline $17^{\text {th }}$ floor & 25.545 & 31.533 \\
\hline $16^{\text {th }}$ floor & 23.534 & 29.226 \\
\hline $15^{\text {th }}$ floor & 21.718 & 26.941 \\
\hline $14^{\text {th }}$ floor & 19.75 & 24.68 \\
\hline $13^{\text {th }}$ floor & 17.997 & 22.449 \\
\hline $12^{\text {th }}$ floor & 16.093 & 20.254 \\
\hline $11^{\text {th }}$ floor & 14.426 & 18.102 \\
\hline $10^{\text {th }}$ floor & 12.608 & 15.998 \\
\hline $9^{\text {th }}$ floor & 11.054 & 13.951 \\
\hline $8^{\text {th }}$ floor & 9.348 & 11.968 \\
\hline $7^{\text {th }}$ floor & 7.94 & 10.059 \\
\hline $6^{\text {th }}$ floor & 6.377 & 8.236 \\
\hline $5^{\text {th }}$ floor & 5.17 & 6.511 \\
\hline $4^{\text {th }}$ floor & 3.793 & 4.901 \\
\hline $3^{\text {rd }}$ floor & 2.82 & 3.479 \\
\hline $2^{\text {nd }}$ floor & 1.743 & 2.203 \\
\hline $1^{\text {st }}$ floor & 1.067 & 1.13 \\
\hline PL & 0.298 & 0.343 \\
\hline GL & 0.105 & 0.044 \\
\hline Base & 0 & 0 \\
\hline & & \\
\hline
\end{tabular}

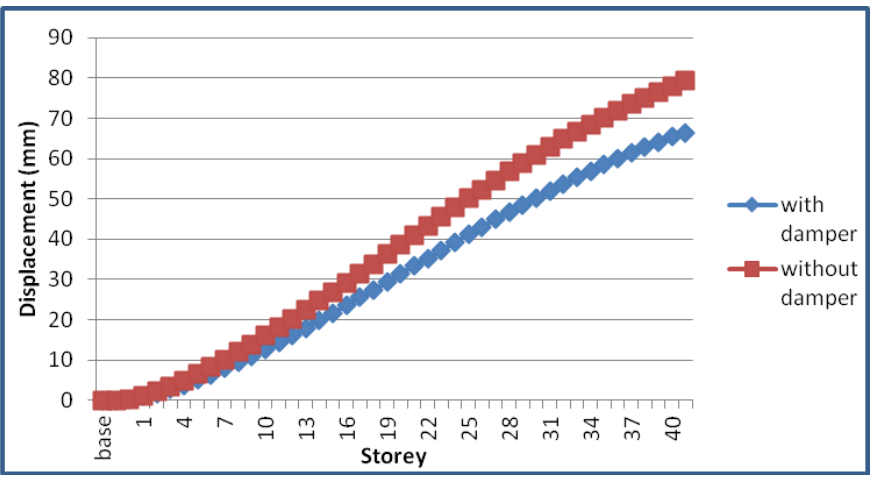

Chart -1(a): Comparison of storey displacement in Zone II (x-direction)

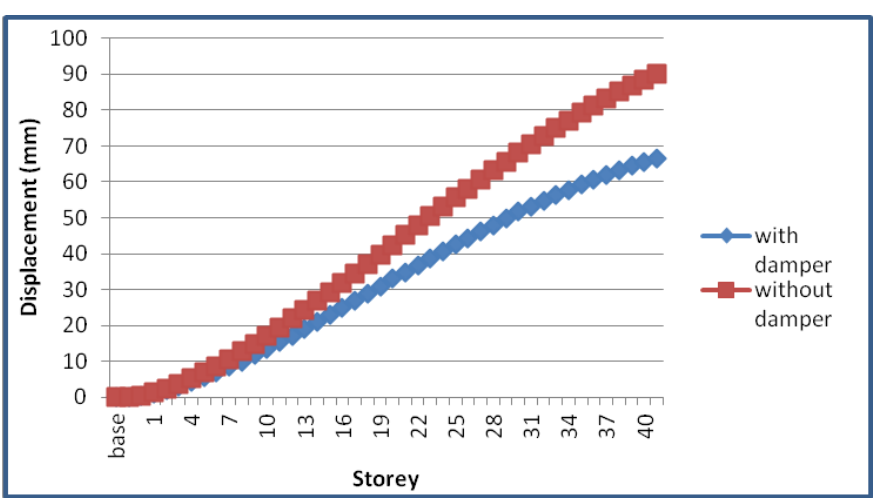

Chart -1(b): Comparison of storey displacement in Zone II (y-direction)

TABLE 3: STORY DISPLACEMENT IN ZONE III (X-DIRECTION)

\begin{tabular}{|c|c|c|}
\hline Storey & With Damper & Without Damper \\
\hline top & 144.194 & 172.414 \\
\hline $40^{\text {th }}$ floor & 142.293 & 169.641 \\
\hline $39^{\text {th }}$ floor & 139.513 & 166.601 \\
\hline $38^{\text {th }}$ floor & 136.626 & 163.389 \\
\hline $37^{\text {th }}$ floor & 133.599 & 160.042 \\
\hline $36^{\text {th }}$ floor & 130.46 & 156.549 \\
\hline
\end{tabular}




\begin{tabular}{|c|c|c|}
\hline $35^{\text {th }}$ floor & 127.249 & 152.905 \\
\hline $34^{\text {th }}$ floor & 123.855 & 149.107 \\
\hline $33^{\text {rd }}$ floor & 120.457 & 145.16 \\
\hline $32^{\text {nd }}$ floor & 116.821 & 141.066 \\
\hline $31^{\text {st }}$ floor & 113.243 & 136.835 \\
\hline $30^{\text {th }}$ floor & 109.386 & 132.474 \\
\hline $29^{\text {th }}$ floor & 105.647 & 127.992 \\
\hline $28^{\text {th }}$ floor & 101.597 & 123.395 \\
\hline $27^{\text {th }}$ floor & 97.719 & 118.696 \\
\hline $26^{\text {th }}$ floor & 93.511 & 113.905 \\
\hline $25^{\text {th }}$ floor & 89.523 & 109.033 \\
\hline $24^{\text {th }}$ floor & 85.194 & 104.092 \\
\hline $23^{\text {rd }}$ floor & 81.131 & 99.093 \\
\hline $22^{\text {nd }}$ floor & 76.721 & 94.049 \\
\hline $21^{\text {st }}$ floor & 72.62 & 88.971 \\
\hline $20^{\text {th }}$ floor & 68.17 & 83.873 \\
\hline $19^{\text {th }}$ floor & 64.074 & 78.769 \\
\hline $18^{\text {th }}$ floor & 59.632 & 73.677 \\
\hline $17^{\text {th }}$ floor & 55.587 & 68.616 \\
\hline $16^{\text {th }}$ floor & 51.21 & 63.597 \\
\hline $15^{\text {th }}$ floor & 47.258 & 58.623 \\
\hline $14^{\text {th }}$ floor & 42.975 & 53.703 \\
\hline $13^{\text {th }}$ floor & 39.162 & 48.849 \\
\hline $12^{\text {th }}$ floor & 35.018 & 44.073 \\
\hline $11^{\text {th }}$ floor & 31.392 & 39.39 \\
\hline $10^{\text {th }}$ floor & 27.435 & 34.812 \\
\hline $9^{\text {th }}$ floor & 24.054 & 30.357 \\
\hline $8^{\text {th }}$ floor & 20.34 & 26.042 \\
\hline $7^{\text {th }}$ floor & 17.277 & 21.888 \\
\hline $6^{\text {th }}$ floor & 13.876 & 17.921 \\
\hline $5^{\text {th }}$ floor & 11.25 & 14.168 \\
\hline $4^{\text {th }}$ floor & 8.254 & 10.665 \\
\hline $3^{\text {rd }}$ floor & 6.136 & 7.57 \\
\hline $2^{\text {nd }}$ floor & 3.793 & 4.793 \\
\hline $1^{\text {st }}$ floor & 2.321 & 2.459 \\
\hline PL & 0.648 & 0.746 \\
\hline GL & 0.229 & 0.096 \\
\hline Base & 0 & 0 \\
\hline
\end{tabular}

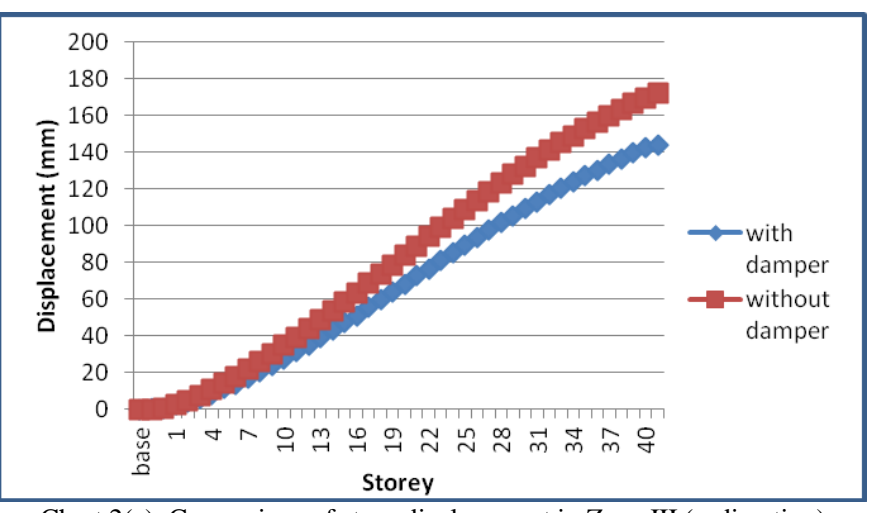

Chart 2(a): Comparison of story displacement in Zone III (x-direction)

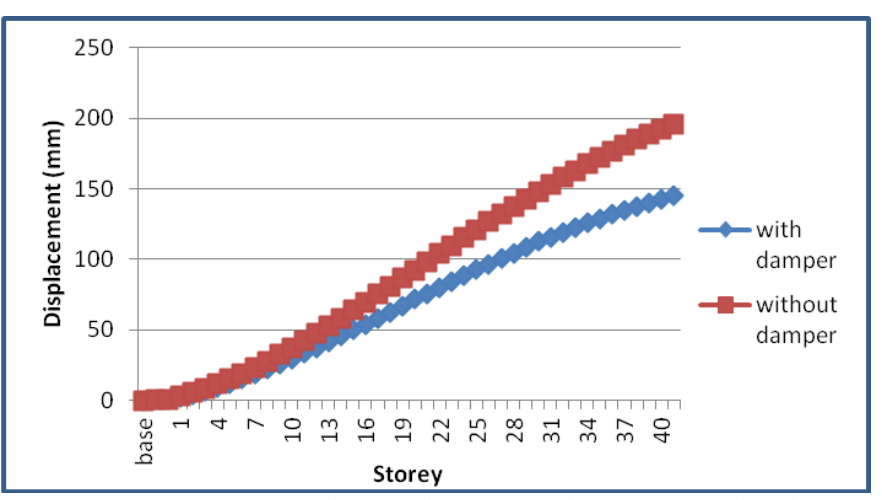

Chart 2(b): Comparison of storey displacement in Zone III (y-direction)
TABLE 4: STOREY DISPLACEMENT IN ZONE IV (X-DIRECTION)

\begin{tabular}{|c|c|c|}
\hline Storey & With Damper & Without Damper \\
\hline top & 265.593 & 317.571 \\
\hline $40^{\text {th }}$ floor & 262.092 & 312.463 \\
\hline $39^{\text {th }}$ floor & 256.971 & 306.865 \\
\hline $38^{\text {th }}$ floor & 251.652 & 300.949 \\
\hline $37^{\text {th }}$ floor & 246.078 & 294.783 \\
\hline $36^{\text {th }}$ floor & 240.296 & 288.35 \\
\hline $35^{\text {th }}$ floor & 234.381 & 281.637 \\
\hline $34^{\text {th }}$ floor & 228.131 & 274.643 \\
\hline $33^{\text {rd }}$ floor & 221.872 & 267.371 \\
\hline $32^{\text {nd }}$ floor & 215.173 & 259.832 \\
\hline $31^{\text {st }}$ floor & 208.584 & 252.038 \\
\hline $30^{\text {th }}$ floor & 201.48 & 244.005 \\
\hline $29^{\text {th }}$ floor & 194.592 & 235.75 \\
\hline $28^{\text {th }}$ floor & 187.133 & 227.283 \\
\hline $27^{\text {th }}$ floor & 179.989 & 218.627 \\
\hline $26^{\text {th }}$ floor & 172.239 & 209.802 \\
\hline $25^{\text {th }}$ floor & 164.894 & 200.829 \\
\hline $24^{\text {th }}$ floor & 156.92 & 191.728 \\
\hline $23^{\text {rd }}$ floor & 149.437 & 182.521 \\
\hline $22^{\text {nd }}$ floor & 141.313 & 173.23 \\
\hline $21^{\text {st }}$ floor & 133.761 & 163.877 \\
\hline $20^{\text {th }}$ floor & 125.564 & 154.487 \\
\hline $19^{\text {th }}$ floor & 118.019 & 145.086 \\
\hline $18^{\text {th }}$ floor & 109.838 & 135.706 \\
\hline $17^{\text {th }}$ floor & 102.386 & 126.384 \\
\hline $16^{\text {th }}$ floor & 94.324 & 117.14 \\
\hline $15^{\text {th }}$ floor & 87.046 & 107.978 \\
\hline $14^{\text {th }}$ floor & 79.156 & 98.916 \\
\hline $13^{\text {th }}$ floor & 72.133 & 89.976 \\
\hline $12^{\text {th }}$ floor & 64.499 & 81.179 \\
\hline $11^{\text {th }}$ floor & 57.821 & 72.552 \\
\hline $10^{\text {th }}$ floor & 50.532 & 64.121 \\
\hline $9^{\text {th }}$ floor & 44.306 & 55.915 \\
\hline $8^{\text {th }}$ floor & 37.465 & 47.967 \\
\hline $7^{\text {th }}$ floor & 31.823 & 40.316 \\
\hline $6^{\text {th }}$ floor & 25.559 & 33.008 \\
\hline $5^{\text {th }}$ floor & 20.721 & 26.096 \\
\hline $4^{\text {th }}$ floor & 15.204 & 19.644 \\
\hline $3^{\text {rd }}$ floor & 11.302 & 13.943 \\
\hline $2^{\text {nd }}$ floor & 6.987 & 8.828 \\
\hline $1^{\text {st }}$ floor & 4.275 & 4.529 \\
\hline PL & 1.193 & 1.374 \\
\hline GL & 0.422 & 0.176 \\
\hline Base & 0 & 0 \\
\hline
\end{tabular}

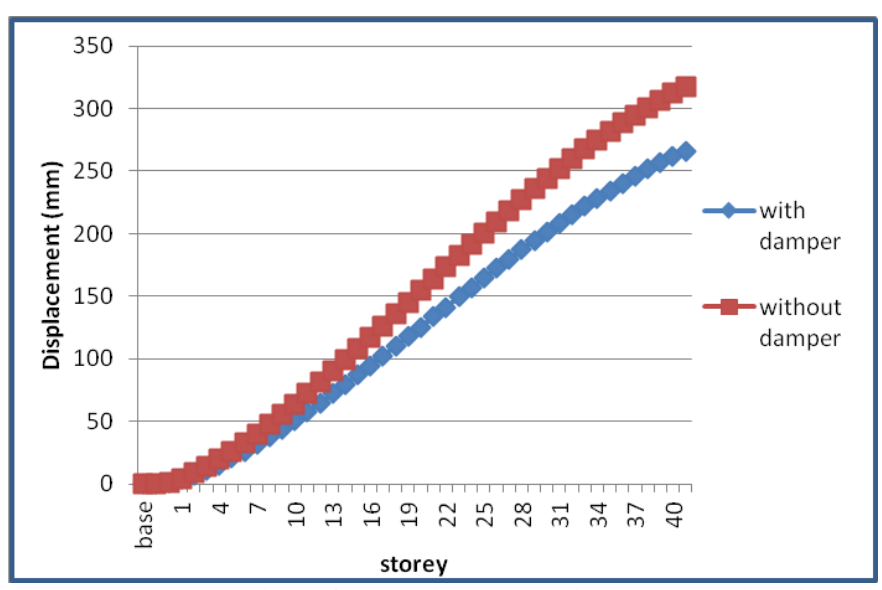

Chart 3(a): Comparison of storey displacement in Zone IV (x-direction) 


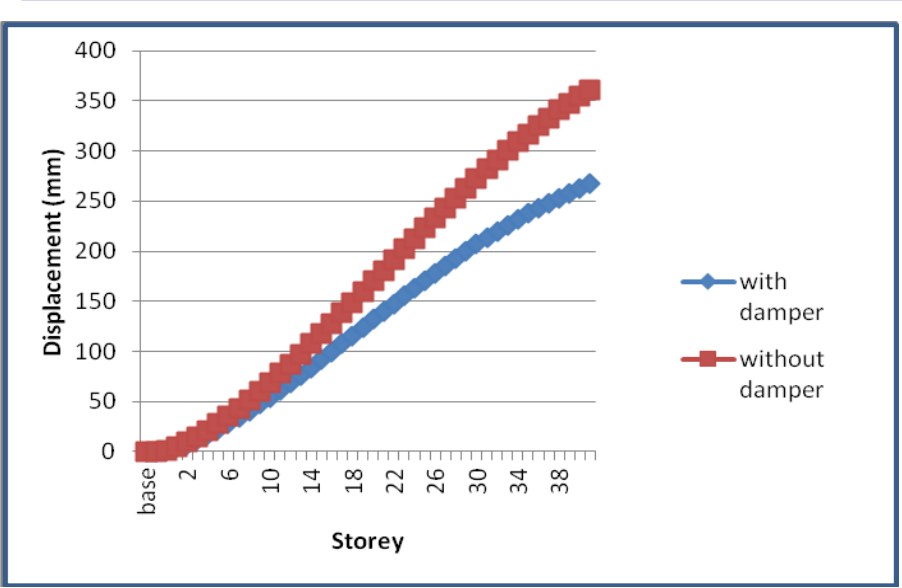

Chart 3(b): Comparison of storey displacement in Zone IV (y-direction)

TABLE 5: STOREY DISPLACEMENT IN ZONE V (X-DIRECTION)

\begin{tabular}{|c|c|c|}
\hline Storey & With Damper & Without Damper \\
\hline top & 430.305 & 524.387 \\
\hline $40^{\text {th }}$ floor & 424.678 & 516.047 \\
\hline $39^{\text {th }}$ floor & 416.464 & 506.927 \\
\hline $38^{\text {th }}$ floor & 407.940 & 497.3 \\
\hline $37^{\text {th }}$ floor & 399.004 & 487.273 \\
\hline $36^{\text {th }}$ floor & 389.745 & 476.814 \\
\hline $35^{\text {th }}$ floor & 380.265 & 465.902 \\
\hline $34^{\text {th }}$ floor & 370.256 & 454.533 \\
\hline $33^{\text {rd }}$ floor & 360.223 & 442.712 \\
\hline $32^{\text {nd }}$ floor & 349.494 & 430.453 \\
\hline $31^{\text {st }}$ floor & 338.926 & 417.775 \\
\hline $30^{\text {th }}$ floor & 327.539 & 404.701 \\
\hline $29^{\text {th }}$ floor & 316.483 & 391.258 \\
\hline $28^{\text {th }}$ floor & 304.514 & 377.458 \\
\hline $27^{\text {th }}$ floor & 293.033 & 363.339 \\
\hline $26^{\text {th }}$ floor & 280.580 & 348.931 \\
\hline $25^{\text {th }}$ floor & 268.760 & 334.265 \\
\hline $24^{\text {th }}$ floor & 255.925 & 319.373 \\
\hline $23^{\text {rd }}$ floor & 243.863 & 304.289 \\
\hline $22^{\text {nd }}$ floor & 230.761 & 289.049 \\
\hline $21^{\text {st }}$ floor & 218.566 & 273.687 \\
\hline $20^{\text {th }}$ floor & 205.320 & 258.241 \\
\hline $19^{\text {th }}$ floor & 193.112 & 242.758 \\
\hline $18^{\text {th }}$ floor & 179.861 & 227.285 \\
\hline $17^{\text {th }}$ floor & 167.779 & 211.885 \\
\hline $16^{\text {th }}$ floor & 154.689 & 196.588 \\
\hline $15^{\text {th }}$ floor & 142.863 & 181.403 \\
\hline $14^{\text {th }}$ floor & 130.021 & 166.357 \\
\hline $13^{\text {th }}$ floor & 118.580 & 151.486 \\
\hline $12^{\text {th }}$ floor & 106.121 & 136.829 \\
\hline $11^{\text {th }}$ floor & 95.215 & 122.426 \\
\hline $10^{\text {th }}$ floor & 83.285 & 108.324 \\
\hline $9^{\text {th }}$ floor & 73.092 & 94.57 \\
\hline $8^{\text {th }}$ floor & 61.861 & 81.223 \\
\hline $7^{\text {th }}$ floor & 52.589 & 68.349 \\
\hline $6^{\text {th }}$ floor & 42.272 & 56.027 \\
\hline $5^{\text {th }}$ floor & 34.310 & 44.347 \\
\hline $4^{\text {th }}$ floor & 25.189 & 33.421 \\
\hline $3^{\text {rd }}$ floor & 18.756 & 23.749 \\
\hline $2^{\text {nd }}$ floor & 11.610 & 15.054 \\
\hline $1^{\text {st }}$ floor & 7.116 & 7.732 \\
\hline PL & 1.988 & 2.344 \\
\hline GL & 0.703 & 0.301 \\
\hline Base & 0 & 0 \\
\hline
\end{tabular}

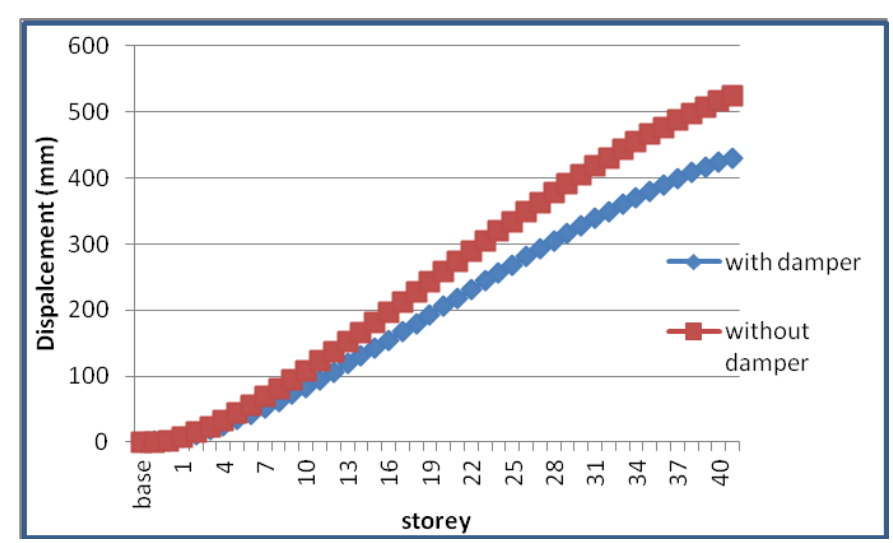

Chart 4(a): Comparison of storey displacement in Zone V (x-direction)

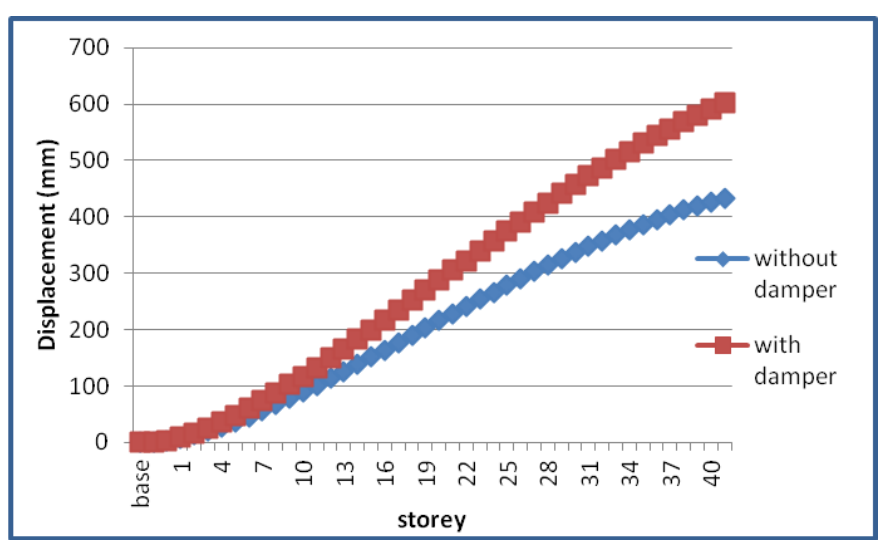

Chart 4(b): Comparison of storey displacement in Zone V (y-direction)

TABLE 6: COMPARISON OF MAXIMUM DISPLACEMENTS OF BUILDING (X-DIRECTION)

\begin{tabular}{|c|c|c|c|c|}
\hline ZONE & II & III & IV & V \\
\hline with damper & 66.266 & 144.195 & 267.07 & 430.3 \\
\hline without damper & 79.234 & 172.41 & 317.57 & 524.387 \\
\hline
\end{tabular}

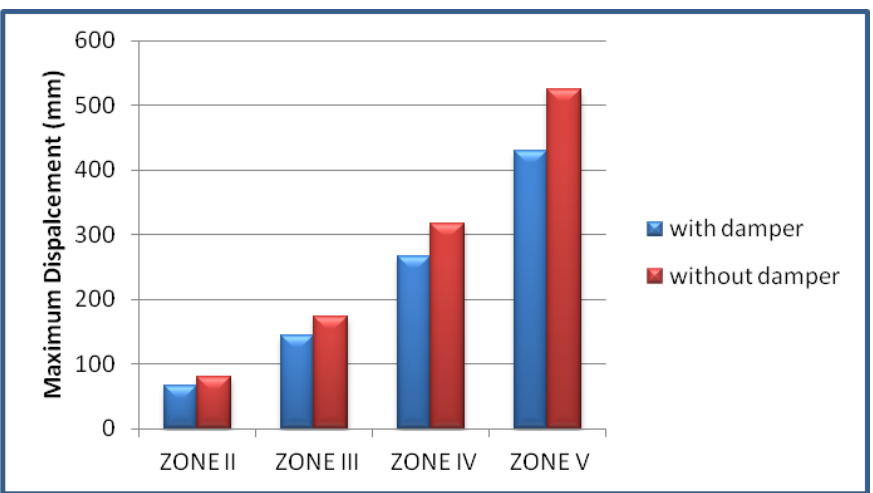

Chart 5(a): Comparison of maximum displacements of building (x-direction)

TABLE 7: COMPARISON OF MAXIMUM DISPLACEMENTS OF BUILDING (Y-DIRECTION)

\begin{tabular}{|c|c|c|c|c|}
\hline ZONE & II & III & IV & V \\
\hline with damper & 66.636 & 145 & 265.59 & 434.029 \\
\hline without damper & 90.069 & 195.96 & 360.99 & 601.809 \\
\hline
\end{tabular}




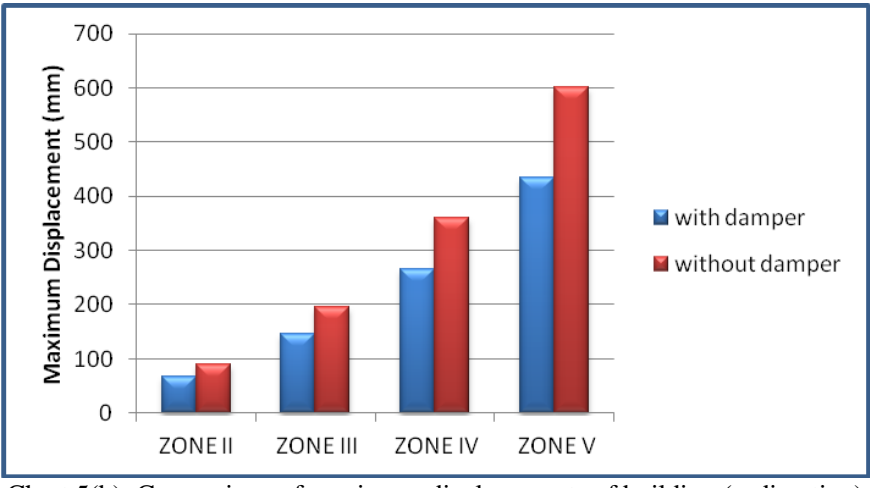

Chart 5(b): Comparison of maximum displacements of building (y-direction)

Building in Zone $\mathrm{V}$ is again analysed for time history analysis with time history data of El-Centro earthquake in order to compare the difference in spectral acceleration, spectral velocity and spectral displacement of building for with damper and without damper condition. The obtained response spectrum curves having 5\% damping are shown below. Table 7 summarizes maximum and minimum values of acceleration, velocity and displacement at $0 \%$ damping and $0.1 \%$ damping.

TABLE 8: MAXIMUM AND MINIMUM VALUES OF RESPONSE SPECTRUM CHARACTERISTICS

\begin{tabular}{|c|c|c|c|c|}
\hline Characteristics & \multicolumn{2}{|c|}{ With damper } & \multicolumn{2}{c|}{ Without damper } \\
\hline \multirow{2}{*}{$\begin{array}{c}0 \% \\
\text { Pseudo spectral } \\
\text { Acceleration } \\
\left(\mathrm{mm} / \mathrm{sec}^{2}\right)\end{array}$} & 4060.08 & 440.9 & 7206.58 & 497.55 \\
\cline { 2 - 5 } & $\begin{array}{c}0 \% \\
\text { damping }\end{array}$ & $\begin{array}{c}0 \% \\
\text { damping }\end{array}$ & 2.5 \\
\hline $\begin{array}{c}\text { Pseudo spectral } \\
\text { velocity (mm } / \mathrm{sec})\end{array}$ & 1092.26 & 2.35 & 1485 & 2.5 \\
\hline $\begin{array}{c}\text { Spectral } \\
\text { displacement(mm) }\end{array}$ & 968.5 & 0.011 & 1492.238 & 0.012 \\
\hline
\end{tabular}

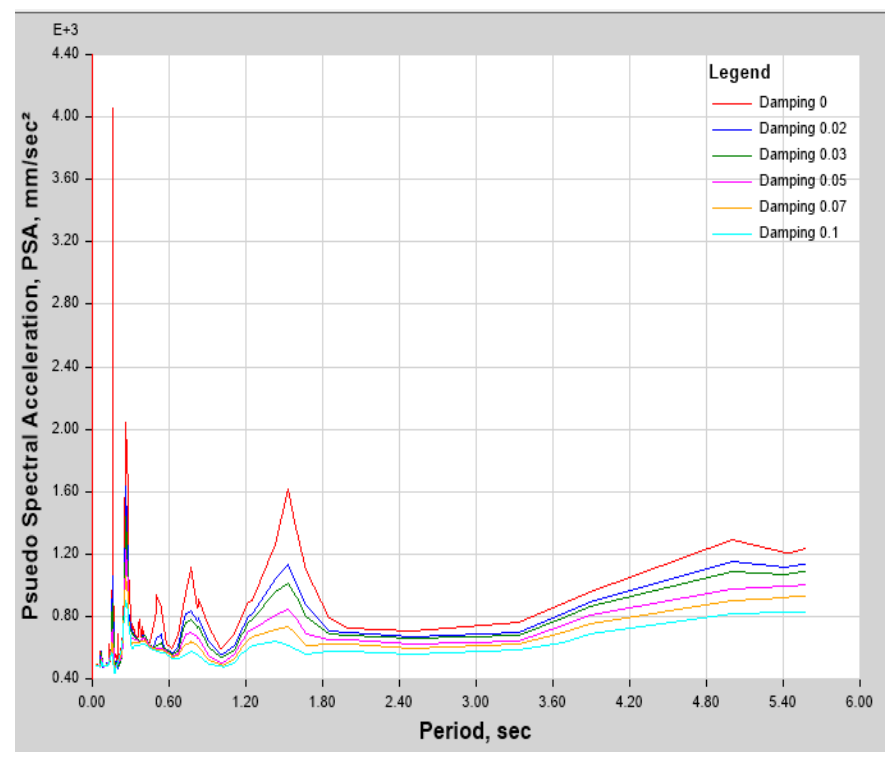

Fig 4(a): PSA Vs Time period (with damper condition)

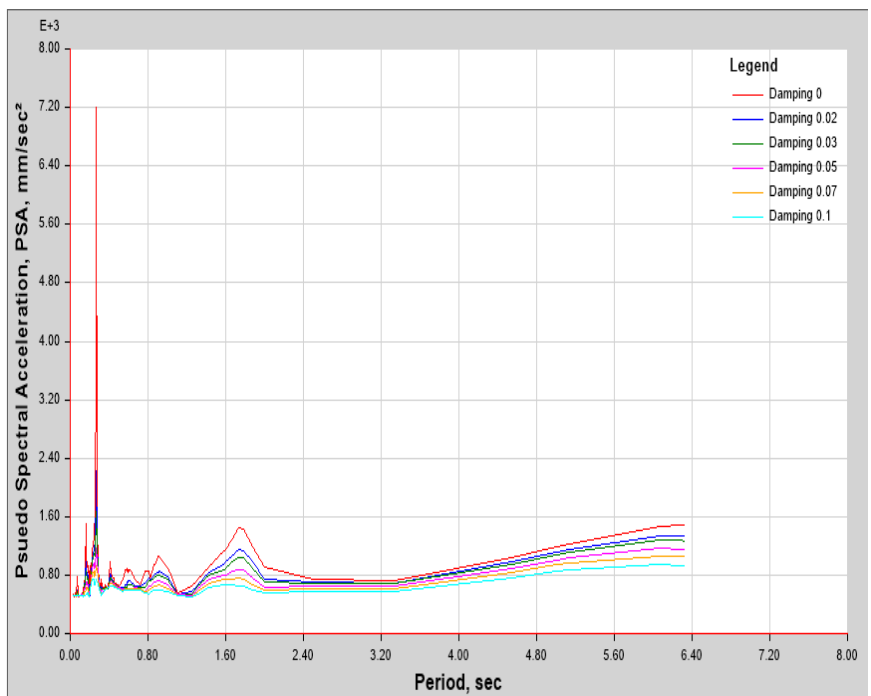

Fig 4(b): PSA Vs Time period (without damper condition)

\section{IV.CONCLUSION}

From Table 6 and Table 7 it is observed that by providing dampers overall displacement of building in each zone is considerably reduced. Percentage reduction in displacement for Zone II, Zone III and Zone IV is approximately $16 \%$ whereas for Zone $\mathrm{V}$ it is approximately $18 \%$ for $\mathrm{x}$-direction. On other hand, for $y$-direction percentage reduction in displacement for Zone II, Zone III and Zone IV is approximately $26 \%$ and for Zone $\mathrm{V}$ is approximately $28 \%$. From Table 7 it is observed that although having 5\% damping in the building, the response spectrum characteristics such as pseudo spectral acceleration, pseudo spectral velocity and spectral displacement are much reduced after the application of dampers in the building. For 0\% damping, pseudo spectral acceleration is reduced by approximately $44 \%$ while for $0.1 \%$ damping it is reduced by approximately $11 \%$. It may be possible to increase the percentage reduction in displacement by increasing the capacity of fluid viscous dampers and the dampers are found to be very effective in reducing earthquake responses.

\section{V.REFERENCES}

[1] Pramodini Naik, Satish Annigeri. "Performance Evaluation Of 9 Storey RC Building Located In North Goa." $11^{\text {th }}$ International Symposium On Plasticity And Impact Mechanics, Implast 2016.

[2] Savita C. Majage, Prof. N. P. Phadtare. "Dynamic Analysis And Design of G+8 Storey RC Structure By Providing Lead Rubber Bearing as Base Isolation System.” International Research Journal of Engineering and Technology. Volume 05 Issue: 08. Aug 2018.

[3] Sayed Mahmoud. "Horizontally Connected High Rise Building Under Earthquake Loading." Ain Shams Engineering Journal 10 (2019) 227-241.

[4] Ji Dongyu, Li Xiaofen. "Seismic Behaviour Analysis of High Rise Connected Structure." International Conference on Mechatronics, Electronic, Industrial and Control Engineering (MEIC 2014).

[5] Surendra Chaurasiya, Sagar Jamle. "Twin Tower High Rise Building Subjected To Seismic Loading: A Review.” International Journal of Advanced Engineering Research And Science. Vol-6, Issue-4, Apr-2019.

[6] A.V. Bhaskararao, R. S. Jangid. "Seismic Response Of Adjacent Buildings Connected With Dampers." $13^{\text {th }}$ World Conference on Earthquake Engineering. Vancouver, B.C., Canada. August 1-6, 2004. Paper No. 3143. 
[7] S. Shamshad Begum, Dr. G. Vani. "Analysis of a High Rise Unsymmetrical Building with Dampers Using Etabs.” 2016 Ijsrst, Volume 2, Issue 3 .

[8] Wensheng LU and Xilin LU, (2000). "Seismic Modal Test And Analysis Of Multi-Tower High-Rise Buildings." 12th World Conference on Earthquake Engineering, Pp. 0281.
[9] Bryan Stafford Smith, Alex Couli.“"Tall Building Structures, Analysis and Design."

[10] Bungale S. Taranath. "Structural Analysis and Design Of Tall Buildings." 